\title{
Carbon stocks and sequestration potential of dry forests under community management in Tigray, Ethiopia
}

\author{
Negasi Solomon ${ }^{1 *}$, Emiru Birhane ${ }^{1,2}$, Tewodros Tadesse ${ }^{3}$, Anna C. Treydte ${ }^{4,5}$ and Kiros Meles ${ }^{6}$
}

\begin{abstract}
Introduction: Forests form a major component of the carbon (C) reserves in the world's ecosystems. However, little is known on how management influences $C$ stocks of woody vegetation, particularly in dry areas. We developed regression models for two dominant tree species to predict $C$ stocks and quantified the potential of community managed forests as $C$ sinks.

Methods: Plots were randomly selected from community-managed natural forest, herbivore exclosures, and from communal grazing land. Tree and shrub biomass were estimated using a regression model on the most dominant woody species while herbaceous biomass was determined using destructive sampling.

Results: The simplest model, based on only one single predictor variable, showed a good fit to the data for both species (Juniperus procera and Acacia abyssinica). Diameter at breast height $\left(r^{2}>0.95\right)$ was a more reliable predictor than height $\left(r^{2}>0.54\right)$, crown diameter $\left(r^{2}>0.68\right)(p<0.001)$. The $C$ content of the total biomass for the managed natural forest and the exclosure were estimated as, 58.11 and $22.29 \mathrm{Mg} \mathrm{ha}^{-1}$, respectively, while that for the grazing land was $7.76 \mathrm{Mg} \mathrm{ha}^{-1}$, and the mean carbon content between the three land uses were significantly different $(p<0.05)$.

Conclusions: We conclude that forests managed by the community have a high potential for $C$ sequestration and storage and their conservation should be promoted.
\end{abstract}

Keywords: Allometric functions, Regression, Dryland, Livestock pressure, Woody and grassy vegetation, Exclosures

\section{Introduction}

Forests form a major component of the carbon (C) reserves in the world's ecosystems (Houghton 2007). Their ecosystem services (ESS) provide income from woody products, non-timber forest products, and fodder, and they play a crucial role in enabling sustainable livelihoods. Despite their wide reaching significance, current deforestation and land degradation are reducing the ability of forested land to support the delivery of these vital ESS (Bishaw 2001). In addition, large-scale deforestation can lead to a reduction in local precipitation and an increase in land surface temperature (Defries et al. 2002). These changes in land cover trigger a chain of feedback

\footnotetext{
* Correspondence: solomonnegasi@gmail.com

${ }^{1}$ Department of Land Resources Management and Environmental Protection, Mekelle University, P.O. Box 231, Mekelle, Ethiopia

Full list of author information is available at the end of the article
}

loops in the climate system as, for instance, vegetation productivity and soil decomposition respond to changes in atmospheric $\mathrm{CO}_{2}$ and climate patterns (Brovkin et al. 2004) and, thereby, impact terrestrial $C$ storage.

Biophysical, environmental, and economic indicators provide strong evidence that natural resources in Ethiopia are currently severely deteriorating (Bojö and Cassells 1995; Hoben 1995; Nyssen et al. 2004). Particularly Ethiopia's deforestation and land degradation entail several socio-economic and environmental challenges that have strongly affected the capacity of forests to provide ecosystem services.

Many developing nations have decentralized the full or partial forest management authority to local communities in pursuit of sustainable forest management (Anderson 2000; Bowler et al. 2010). In Ethiopia, sustainable utilization and conservation of forest resources 
at community level have been considered as important components of poverty alleviation and a sustainable development strategy (Tesfaye 2011). Since its promulgation in 1995, the current Ethiopian constitution provides latitude for decentralization of power in the forest sector. Further, youth farming has been promoted and forests are protected by the local communities and members who use their own rules and sanctions to manage the community forests. By promoting agroecological benefits through regeneration and expansion of forest cover, community members also make use of the forests for economic purposes.

In Tigray, northern Ethiopia, land degradation and consecutive soil erosion over many centuries (Darbyshire et al. 2003; Fitsum et al. 1999) have resulted in scarce vegetation cover and productivity (Bishaw 2001; Gebremedhin et al. 2003; Nyssen et al. 2009), which directly impacts livelihoods, particularly those of pastoralists.

Community forestry has, thus, been considered as an effective strategy to achieve the multiple goals of sustainable resource management and poverty alleviation (Bray et al. 2009). Research shows that there are a number of key factors underpinning successful community forest management (CFM) initiatives. A meta-analysis study encompassing 69 cases around the world identified the following as variables that have a significant influence on the success of community forestry: tenure security, clear ownership, congruence between biophysical and socioeconomic boundaries of the resources, effective enforcement of rules and regulations, monitoring, sanctioning, strong local leadership and organization, expectation of benefits, common interests among community members, and local authority (Pagdee et al. 2006).

Programs promoting CFM are usually designed to provide the communities with the forest products they require for their subsistence (firewood, fodder, etc.) while maintaining this off-take at sustainable levels to support natural regeneration processes (Skutsch and Solis 2011).

There is increasing evidence that CFM enhances carbon storage; an analysis of 80 forests across 10 countries shows that community forest management is associated with high levels of carbon storage (Chhatre and Agrawal 2009). Further, a study by Mekuria (2013) in exclosures established on communal grazing lands in Ethiopia showed that higher carbon stocks than adjacent grazing lands. In addition, in Bale Mountains of Ethiopia higher carbon stock was recorded in moist non-degraded forest than moist degraded forest and dry degraded forest (Watson et al. 2013). A study in Handei Village Forest Reserve and Kitulangalo Forest Area, Tanzania showed that increasing in forest carbon stock as a result of the management practices used by the villagers (Zahabu 2006a, 2006b). A study in Tomboroconto forest, Senegal also showed that an increase of about $10 \%$ in carbon stocks, or more than $7 \mathrm{t}$ carbon dioxide per hectare per year, as a result of management activities (Ba 2006).

Biomass and carbon stock estimates for tropical dry forest species improves our comprehension of the significance of tropical dry forests in the global carbon cycle. To successfully implement mitigating policies and take advantage of the Reducing Emissions from Deforestation and Forest Degradation (REDD+) program (Chaturvedi et al. 2011), developing countries need genuine estimates of forest carbon stocks. Consequently, there is an urgent need to quantify tree biomass through direct or indirect methods (Brown 2002). Direct methods calculate biomass destructively by harvesting the tree and measuring the actual mass of each of its components like the tree trunk, leaves and branches (Kangas and Maltamo 2006). Though very accurate (Henry et al. 2011), cutting down trees is both costly time consuming and it is not feasible for a largescale analysis (Condit 2008; Ravindranath and Ostwald 2008; Supriya Devi and Yadava 2009). Indirect methods using allometric relationship to estimate tree biomass are time efficient and less expensive as compare to destructive method (Vashum and Jayakumar 2012). However, tools for biomass estimation remain scarce in the tropics and existing generalized models do not accurately represent biomass in the actual forests (Henry et al. 2011). Though great efforts have been made to develop models for several tropical species in recent years, particularly in Africa (Chave et al. 2014; Fayolle et al. 2013; Henry et al. 2011; Mate et al. 2014; Ngomanda et al. 2014), efforts to develop biomass equations for sub-Saharan Africa have been very restricted (Henry et al. 2011). To obtain precise and accurate biomass and carbon stock estimates in forests, different models must be developed for different species and forest types. Developing site specific allometric equation can be useful input for REDD+ program and other programs to accurately estimate carbon stocks of forest resources.

To date, to our knowledge, there has not been a direct and comprehensive study of carbon (C) stocks and sequestration potential of community managed forests across Ethiopia. Hence, with this paper, we aim at meeting two objectives. The first is to develop a biomass estimation model for the dominant woody vegetation in the community-managed forests. Second, we aim at comparing the $C$ stock potential among two community-managed forests, exclosures, and grazing land. We used field work (destructive sampling) as well as allometric equations to estimate biomass and $\mathrm{C}$ contents of the two dominant woody species as well as the herbaceous layer across the three land use types. The findings of the study are expected to have major implications for policy-makers, researchers, extension 


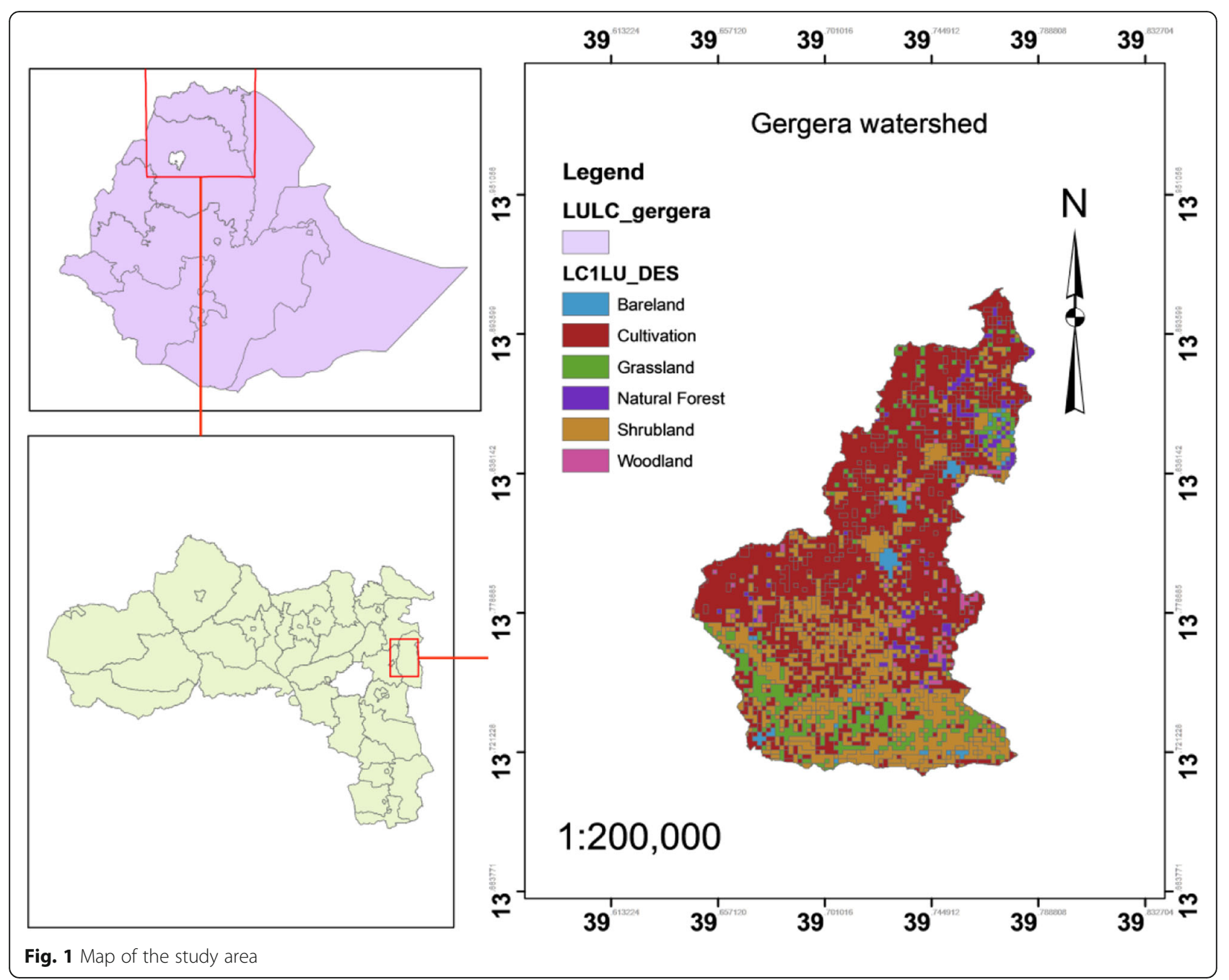

practitioners, and local communities on expanding and valuing community forest management. Therefore, an estimation of biomass and sequestered $\mathrm{C}$ of community forest provides a predictive framework for identifying forests with high biomass $\mathrm{C}$ stocks and inform policymakers about the role of community-managed forests in climate change mitigation.

\section{Methods}

\section{Study area}

Gergera watershed is located in Atsbi-Wonberta District, Eastern Tigray, Northern Ethiopia $\left(39^{\circ} 30^{\prime}-39^{\circ} 45^{\prime} \mathrm{E}\right.$ and $13^{\circ} 30^{\prime} 13^{\circ} 45^{\prime}$ N) (Fig. 1) at an altitude of 1500-2800 masl. Average daily temperatures are between 15 and $30^{\circ} \mathrm{C}$, and its mean annual rainfall is about $529 \mathrm{~mm}$, exceeding the potential evapotranspiration in only 2 months (July and August) of the year (Berhane 2008). The study area is drought prone with erratic, unevenly distributed rainfall and a high run-off (Bekele et al. 2012). The total forest area of the watershed is $9908 \mathrm{ha}$, and soils are categorized as sand in the basin, sandy loam, clay and sandy clay loam, and clay based on the USDA soil textural classification (Bekele et al. 2012). Major soils of the watershed are vertisols, cambisols, and leptosols soils (Bekele et al. 2012). Indigenous trees such as Juniperus procera and Acacia abyssinica are the dominant tree species in the watershed while Eucalyptus spp. are found in the settlement areas and in protected areas (personal observation). Grassland is mainly found in the central lowland area (Berhane 2008), dominated by Cynodon dactylon and Hyperrhenia hirta. Land use and land cover in the watershed are categorized as cultivated land, forest land, grassland, and homestead (Berhane 2008). The dominant livestock are cattle, sheep, and goat. Gergera watershed is characterized by flat to rugged mountain ranges with slopes varying from 2 up to $80 \%$.

The people of Gergera watershed exercise rain-fed, subsistence-oriented mixed crop-livestock production farming. The major crops and vegetables grown in the area are Eragrostis teff (teff), Hordeum vulgare (barley), 
Zea mays (maize), Triticum aestivum (wheat), and Phaseolus vulgaris (bean). Recently, farmers have introduced fruit trees such as Persea Americana, Psidium guajava, Musa, and Carica papaya.

\section{Data collection}

We selected sites with managed natural forest and livestock exclosures as community-managed forest sites and compared these with sites in separate adjacent free grazing land as control sites, ensuring that soil and terrain conditions were as similar as possible between each site. The data were collected from three community managed natural forest sites, three exclosure sites, and three adjacent grazing land sites. The grazing land was adjacent to both the managed natural forest and exclosure.

- Community-managed natural forests. A forest, in which management has substantially altered the structure and ecological processes such as the water cycle, biogeochemical (or nutrient) cycling, energy flow, and community dynamics. The management focuses on the importance of participation and benefit-sharing (Agrawal et al. 2008; Sunderlin et al. 2008). However, growth is still mainly a natural process with no regular and/or continuous human intervention. The dominant tree species in the study area are J. procera and A. abyssinica, and the woody cover of the forest was visually estimated to be $>60 \%$. The economic and social benefits of community forest to the local community comprised collecting dead wood, fodder, and roof grass and providing income from beekeeping activities. Collecting live trees from the natural forest was prohibited.

- Exclosures. Areas closed from the interference of humans and domestic animals with the goal of promoting natural plant regeneration of formerly degraded communal grazing lands, often located along steep previous grazing lands (Aerts et al. 2009). Dominant tree species also $J$ procera and $A$. abyssinica while the most dominant grass species are Cynodon dactylon and Hyperrhenia hirta. Woody cover was visually estimated to be $50-60 \%$

- Open grazing land. Former forest areas that had been converted into open grazing lands. The sites are dominated by $C$. dactylon and $H$. hirta grasses that are grazed by cattle, donkey sheep, and goat throughout the year. Only few individuals of $J$. procera and $A$. abyssinica species are present.

Stratified random sampling based on land use was applied to achieve precise woody biomass and $\mathrm{C}$ stock estimates. First, the type of land uses was identified. Then, in each land use type we laid out 3 parallel line transects of $200 \mathrm{~m}$ length, randomly. At every $100 \mathrm{~m}$, sample plots of $5 \mathrm{~m} \times 40 \mathrm{~m}$, and $0.5 \mathrm{~m} \times 0.5 \mathrm{~m}$ (within the main plot) size were established for trees and shrub assessment, and grass and herb sampling, respectively (Hairiah et al. 2011). In each land use type, 9 plots with a size of 0.02 ha each were distributed. Overall, a total of 27 (3 plots, "3 sites, and "3 land uses) sample plots were selected for biomass and $\mathrm{C}$ stock sampling from all three land use types.

The number of plots was estimated from reconnaissance survey prior to the main study, whereby, seven plots were established randomly in order to obtain the coefficient of variation $(\mathrm{CV})$. Number of plots were calculated using the following formula (Pearson et al. 2005):

$$
n=\frac{\left(\sum_{i=1}^{n} \mathrm{Ni} * \mathrm{Si}\right)^{2}}{\frac{N^{2} * E^{2}}{t^{2}}+\left(\sum_{i=1}^{n} \mathrm{Ni} * \mathrm{Si}^{2}\right)}
$$

Where:

$E=$ allowable error or the desired half-width of the confidence interval. Calculated by multiplying the mean carbon stock by the desired precision (that is, mean carbon stock $\times 0.1$, for $10 \%$ precision, or 0.2 for $20 \%$ precision),

$t=$ the sample statistic from the $\mathrm{t}$-distribution for the $95 \%$ confidence level. $t$ is usually set at 2 as the sample size is unknown at this stage,

$\mathrm{Ni}=$ number of sampling units for stratum i (area of stratum in hectares or area of the plot in hectares),

$n=$ number of sampling units in the population

$s i=$ standard deviation of stratum i.

The field inventory was carried out in 2012 from the end of September till November. At each plot, the diameter at breast height $(\mathrm{DBH})$ and height $(\mathrm{H})$ of all trees and shrubs with $\mathrm{DBH} \geq 2 \mathrm{~cm}$ were measured using calipers and a 5-m pole graduated with $10 \mathrm{~cm}$ markings, respectively (Giday et al. 2013). Trees taller than $5 \mathrm{~m}$ were measured using clinometers positioned at $10 \mathrm{~m}$ distance from the base of the tree and focused on the highest point of the tree (Ubuy et al. 2014). Further, crown diameter (CD) of every tree and shrub within the plot was measured. The crown diameter measurement was based on the average width of the east west and north south tree crown measurement using a measuring tape.

For developing the species specific allometric equations, the two most dominant woody species (Aynekulu 2011), namely, A. abyssinica and J. procera, were destructively sampled. A total of 39 individuals of the two species of interest (25 individuals for J. procera, 14 A. abyssinica) were identified and tagged for destructive sampling from a DBH classes of $2.5-10 \mathrm{~cm}$, $10-20 \mathrm{~cm}, 20-30 \mathrm{~cm}, 30-40 \mathrm{~cm}, 40-60 \mathrm{~cm}$ and $>60 \mathrm{~cm}$ 
(Hairiah et al. 2011). Stratified random sampling was used to select trees per each DBH class to harvest for biomass measurements. However, as more than $97 \%$ of the trees had a diameter $<16 \mathrm{~cm}$, no tree was felled within the larger diameter classes. Besides, felling the trees was restricted in the area as the land was a designated for the rehabilitation. Prior to harvest, diameter, height and crown diameter were measured to calculate predictor variable values for our allometric equations. After dendrometric measurements, the aboveground biomass (AGB) of each woody plant was harvested to ground level. Due to the difference in moisture content, the tree material was separated into leaves, twigs (diameter $<3.2 \mathrm{~cm}$ ), small branches (diameter 3.2-6.4 cm), large branches (diameter $>6.4 \mathrm{~cm}$ ) and stem (Ketterings et al. 2001). The stem was debranched, and stem and branches were cut into sections to facilitate weighing in the field. Each component of the plant was weighed to the nearest $100 \mathrm{~g}$ using a spring balance, and the fresh weight was recorded in the field. A total of 39 fresh biomass subsample of 250-500 $\mathrm{g}$ for each stem, gross branch and thin branch and leave component was brought to the laboratory for dry biomass determination, dried to constant mass for $72 \mathrm{~h}$ at $105{ }^{\circ} \mathrm{C}$ (Ketterings et al. 2001) and weighted to the nearest $10 \mathrm{~g}$. A total of 27 (9 per land use) composite samples of grasses were collected from all land uses.. Fresh samples were weighed in the field with a $0.1 \mathrm{~g}$ precision balance; and a well-mixed sub-sample of grasses was then placed in a marked bag. The sub-sample was used to determine an oven-dry-to-wet mass ratio that is used to convert the total wet mass to oven dry mass. Finally, the sample disks of stems, branches, and leaves were oven dried at Mekelle University Forestry laboratory at a temperature of $105^{\circ} \mathrm{C}$ until a constant weight were achieved and measured for their dry weight using a digital sensitive balance with a precision $0.1 \mathrm{~g}$.

\section{Data analysis \\ Biomass function and estimation for dry weight determination}

Green weights in the field were transformed to a standardized oven dry weight to develop regression models of the two species. Dry weight ratio was determined by dividing the dry weight (dwdisk) of each sample (leaves, branch, and stem) by its corresponding fresh weight (fwdisk in g). Using this ratio, the dry weight of each component of a tree was calculated as follows:

$$
\begin{aligned}
& \mathrm{SDW}=\frac{\text { dwdisk }}{\text { fwdisk }} * \text { SFW } \\
& \mathrm{BDW}=\frac{\text { dwdisk }}{\text { fwdisk }} * \mathrm{BFW}
\end{aligned}
$$

$$
\text { LDW }=\frac{\text { dwdisk }}{\text { fwdisk }} * \text { LFW }
$$

Where, SDW, BDW, LDW, SFW, BFW, and LFW are the dry and fresh weights of the stem, branch, and leaf parts of the tree in $\mathrm{kg}$, respectively. The total dry weight (TDW) of the tree was calculated as

$$
\mathrm{TDW}=\mathrm{SDW}+\mathrm{BDW}+\mathrm{LDW}
$$

Where SDW is the stem dry weight BDW is the branch dry weight of the tree and LDW is the leaf dry weight of the tree measured in $\mathrm{kg}$, respectively.

\section{Development of biomass estimation model}

Values of SDW, BDW, LDW, and TDW were determined and entered as dependent variables to develop regression functions with $\mathrm{DBH}, \mathrm{H}$, and $\mathrm{CD}$ as predictor variables based on previous studies made at similar sites (Eshete and Ståhl 1998; Yigardu 2001) and biomass functions were developed. Several alternative functions were tested by introducing $\mathrm{DBH}, \mathrm{H}$, and $\mathrm{CD}$, to test for their ability in predicting total above ground dry biomass.

\section{Tree and shrub biomass estimation}

For the two dominant species, AGB of trees was estimated on the basis of the developed allometric equations. The non-dominant woody species were too few for developing species-specific biomass functions. The biomass functions of the dominant species can be used for biomass estimations of the co-occurring non-dominant species is a legitimate compromise to using other generalized functions reported from different locations in Ethiopia and elsewhere (Gessesse 2016). Allometric equations given by (Brown 1997) were also used to estimate above ground biomass for another species available in the study area. Root biomass was estimated from root-shoot ratios (R/S) as $25 \%$ of above ground biomass (Cairns et al. 1997).

\section{Total biomass estimation}

The total biomass and the biomass per hectare were calculated using the biomass of the different vegetation layers (trees, shrubs, and herbaceous layers). Before calculating the total biomass, the different layers were converted to the same unit, i.e. $\mathrm{Mg} / \mathrm{ha}$. The total biomass was calculated as the sum of all biomass layers for each plot and averaged over all plots.

$$
\begin{aligned}
\text { Total biomass } & =\text { tree biomass }+ \text { shrub biomass } \\
& + \text { herb biomass }
\end{aligned}
$$

\section{Estimation of total carbon stock}

For the conversion of tree biomass to carbon stocks, we considered a common proxy based on the assumption 
that $50 \%$ of the biomass is carbon (Malhi et al. 2004; Roy et al. 2001). The carbon stock was calculated by summing the individual carbon pools of each stratum using the following formula:

$$
C=C(\mathrm{~TB})+C(\mathrm{SB})+C(H)
$$

Where $\mathrm{C}=$ carbon stock density $\left[\mathrm{Mg} \mathrm{C} \mathrm{ha}^{-1}\right], \mathrm{C}(\mathrm{TB})=$ carbon in tree biomass $\left[\mathrm{Mg} \mathrm{Cha}{ }^{-1}\right]$,

$\mathrm{C}(\mathrm{SB})=$ carbon in shrub biomass $\left[\mathrm{Mg} \mathrm{C} \mathrm{ha}{ }^{-1}\right]$, and $\mathrm{C}(\mathrm{H})=$ carbon in herbaceous biomass $\left[\mathrm{Mg} \mathrm{C} \mathrm{ha}^{-1}\right]$.

\section{Statistical analysis}

Non-linear power function techniques were used to develop allometric models from predictor parameters and their interactions to predict individual woody plant branch and stem biomass and total AGB separately for the selected two woody species. We also explored the use of linear regression models for estimating biomass. In both cases, the final model choice was based on the analyses of residuals. We decided to use power functions because all relationships examined showed a better fit to the non-linear power function compared to the log- linear function. Generalized linear models (GLM) (SAS 2002) were used for the analysis of the goodness of fit for all regression equations. The goodness of fit was determined by examining $p$ values, the coefficient of determination $\left(r^{2}\right)$, and the coefficient of variation $(\mathrm{CV})$. The difference between the chosen fit and the predictors and their interactions for each plant dry biomass was regarded significant if the 95\% confidence intervals (CI) did not overlap. Prior to ANOVA, data was tested for normality and equality of variance and Tukey HSD post hoc tests were performed to separate biomass and $\mathrm{C}$ stock means across land uses. Statistical tests were performed with SAS 9.0 and statistical mean differences were considered significant at $p<0.05$.

\section{Results}

\section{Biomass predictions through allometric equations}

The goodness of fit analysis for the models across both species indicated that the species-specific regression models relating biomass with selected dendrometric predictor variables were highly significant $(p<0.01)$. In general, the results showed that the total dry AGB was

Table 1 Average ( \pm standard error) woody plant dendrometric variables and total dry aboveground biomass (AGB) for the sample woody plants $(n=39)$ in the Gergera watershed, Ethiopia

\begin{tabular}{lllll}
\hline Species & $\mathrm{DBH}$ & $\mathrm{H}$ & $\mathrm{CD}$ & $\mathrm{AGB}$ \\
& $(\mathrm{cm})$ & $(\mathrm{m})$ & \multicolumn{1}{l}{$(\mathrm{m})$} & $(\mathrm{kg})$ \\
\hline Juniperus procera & $7.57 \pm 0.49$ & $5.01 \pm 0.20$ & $5.09 \pm 0.27$ & $26.77 \pm 2.6$ \\
Acacia abyssinica & $5.95 \pm 0.56$ & $4.1 \pm 0.36$ & $4.45 \pm 0.24$ & $17.68 \pm 3.32$ \\
\hline
\end{tabular}

$D B H$ diameter at breast height, $H$ height, $C D$ crown diameter
Table 2 Allometric functions of the best fits for the different tree dendrometric variables: Diameter at breast height (DBH), height $(H)$, crown diameter $(C D)$ and total above ground dry biomass (AGB) in the Gergera watershed, Ethiopia

\begin{tabular}{llllll}
\hline $\begin{array}{l}\text { Woody } \\
\text { species }\end{array}$ & $\begin{array}{l}\text { Dependent } \\
\text { variable }\end{array}$ & $\begin{array}{l}\text { Allometric } \\
\text { equation }\end{array}$ & $r^{2}$ & \multicolumn{1}{l}{$r$} & $p$ \\
\hline $\begin{array}{l}\text { Juniperus } \\
\text { procera }\end{array}$ & $A G B$ & $A G B=1.12 \times D B H^{1.54}$ & 0.95 & 531.95 & $p<0.001$ \\
& $A G B$ & $A G B=1.13 \times C D^{1.9}$ & 0.68 & 49.18 & $p<0.001$ \\
& $A G B$ & $A G B=1.43 \times H^{1.79}$ & 0.54 & 28.06 & $p<0.001$ \\
Acacia & $A G B$ & $A G B=0.55 \times D B H^{1.89}$ & 0.97 & 438.13 & $p<0.001$ \\
abyssinica & $A G B$ & $A G B=0.74 \times H^{2.15}$ & 0.93 & 177.69 & $p<0.001$ \\
& $A G B$ & $A G B=0.11 \times D^{3.27}$ & 0.78 & 43.6 & $p<0.001$ \\
\hline
\end{tabular}

accurately predictable $\left(r^{2} \geq 0.95\right)$ and that all models allowed for sound AGB estimates of the studied species based on their dendrometric measurements (Table 1). The simplest model, based on only one single predictor variable, showed a good fit to the data for $J$. procera (Table 2). Diameter at breast height (DBH) alone was an effective predictor variable for estimating total dry AGB $\left(r^{2}=0.95\right)$ while height $(\mathrm{H})$ had the poorest fit $\left(r^{2}=0.54\right)$ and crown diameter $(\mathrm{CD})$ was intermediate $\left(r^{2}=0.68\right.$; Figs. 2, 3 and 4). Similarly, DBH alone was an effective predictor variable for estimating total dry AGB of $A$. abyssinica (Fig. 2).

\section{Carbon stocks in plant biomass}

Tree $\mathrm{C}$ stocks were significantly four and ten times as high in community-managed natural forests compared to exclosures and open grazing land, respectively. However, shrub and herbaceous biomass were significantly higher in exclosures, followed by community-managed natural forest and open grazing land (Table 3). Above ground tree $\mathrm{C}$ accounted for $70.5,52.1$, and $59.3 \%$ of the total $\mathrm{C}$ in the community-managed natural forest, in exclosures and in the grazing land, respectively. Therefore, in all land uses tree AGB contributed most strongly to the overall $\mathrm{C}$ stocks compared to the other vegetation layers (Table 3).

\section{Discussion}

A systematic selection of the best-fitting regression models for estimating AGB and woody plant components showed that DBH can reliably be used as a predictor variable. The allometric equations were relatively satisfactory for predicting total AGB of J. procera and $A$. abyssinica since total variation explained by the relationship was above $90 \%$. As proven in many allometric studies, stem diameter is the most powerful variable that usually explains most of the variability in observed tree biomass (Zianis and Seura 2005). Similarly, Hasen-Yusuf et al. (2013) and Giday et al. (2013) reported that stem diameter explains most of the variability in observed tree 


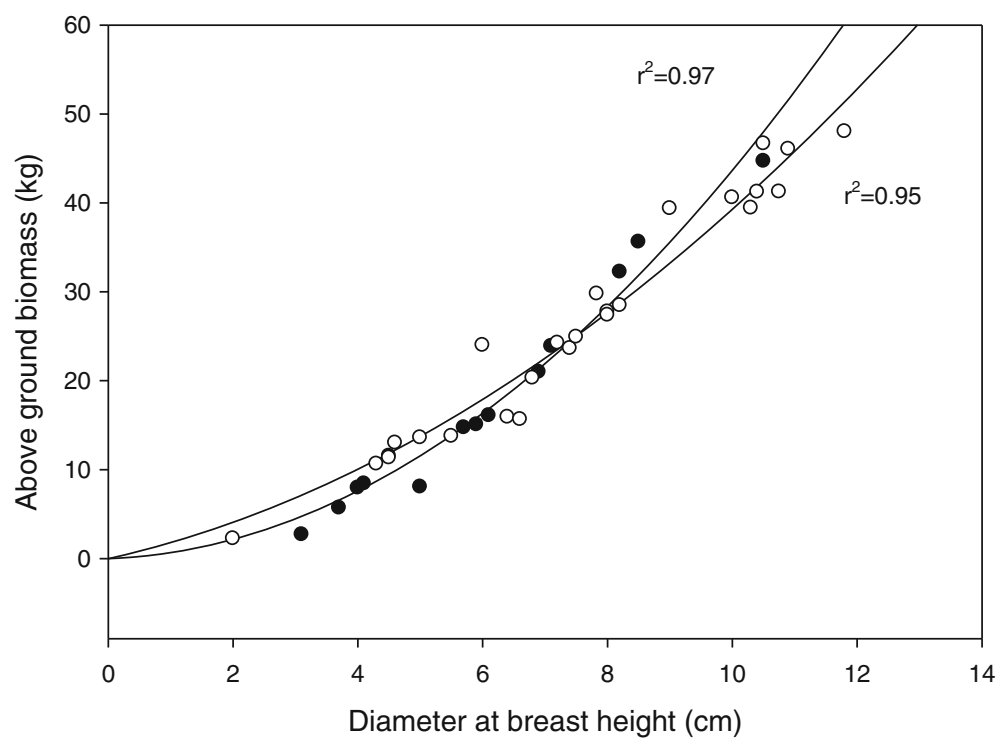

Fig. 2 Regression lines of total dry biomass (in $\mathrm{kg}$ ) versus diameter at breast height (DBH) (open circles) for Juniperus procera and (filled circles) for Acacia abyssinica

biomass in semi-arid rangelands, Ethiopia. Our result is also in line with the findings of Tietema (1993), Malimbwi et al. (1994), Eshete and Ståhl (1998), and Yigardu (2001). Actual model performance, expressed as a goodness of fit, depended on both species involved and the biomass component estimated in our study.

We have shown that the biomass of total AGB could be predicted with good precision for both of the species studied. Generally, our models indicated that the most important single or set of predictor variable/s were represented by the diameter at breast height for both tree species, which are common across the highlands of Ethiopia (Aynekulu 2011). Therefore, developing allometric equations of these two species is highly valuable. Our allometric equations were statistically robust and can be used to estimate tree biomass in other regions provided that the woody species are similar and the climatic zone is alike, for instance in dry afromontane forests of Ethiopia.

Our total carbon stock estimates were comparable with the results reported by Alemu (2012) for woodlands of Northern Ethiopia. Compared to the aboveground

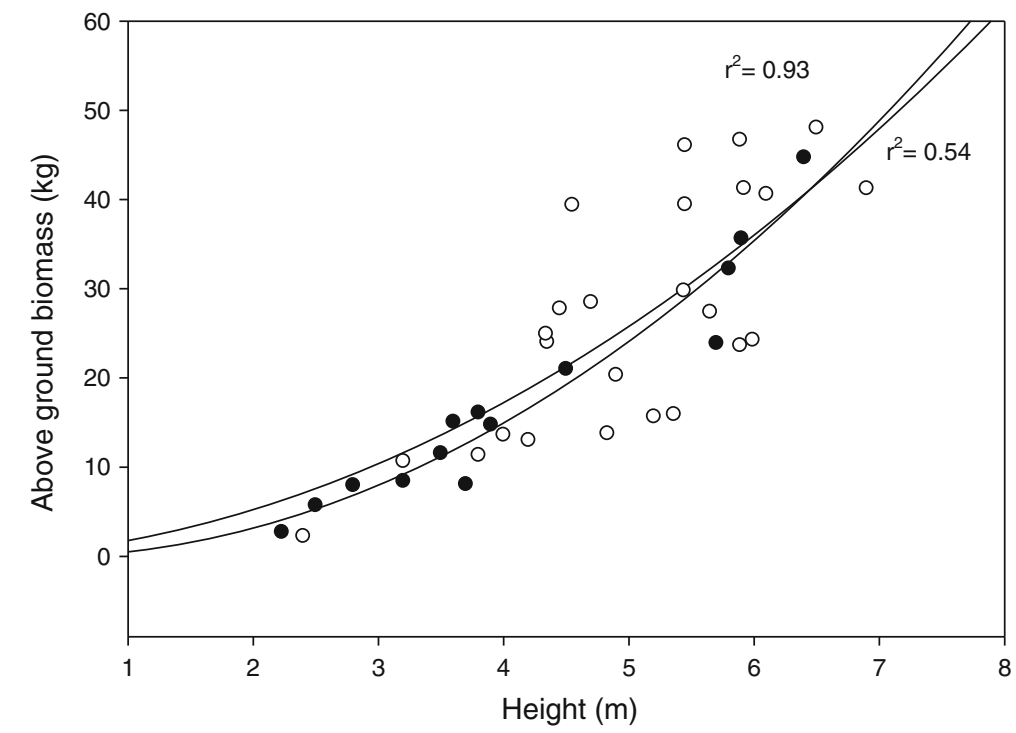

Fig. 3 Regression lines of total dry biomass (in $\mathrm{kg}$ ) versus height (H) (open circles) for Juniperus procera and (filled circles) for Acacia abyssinica 


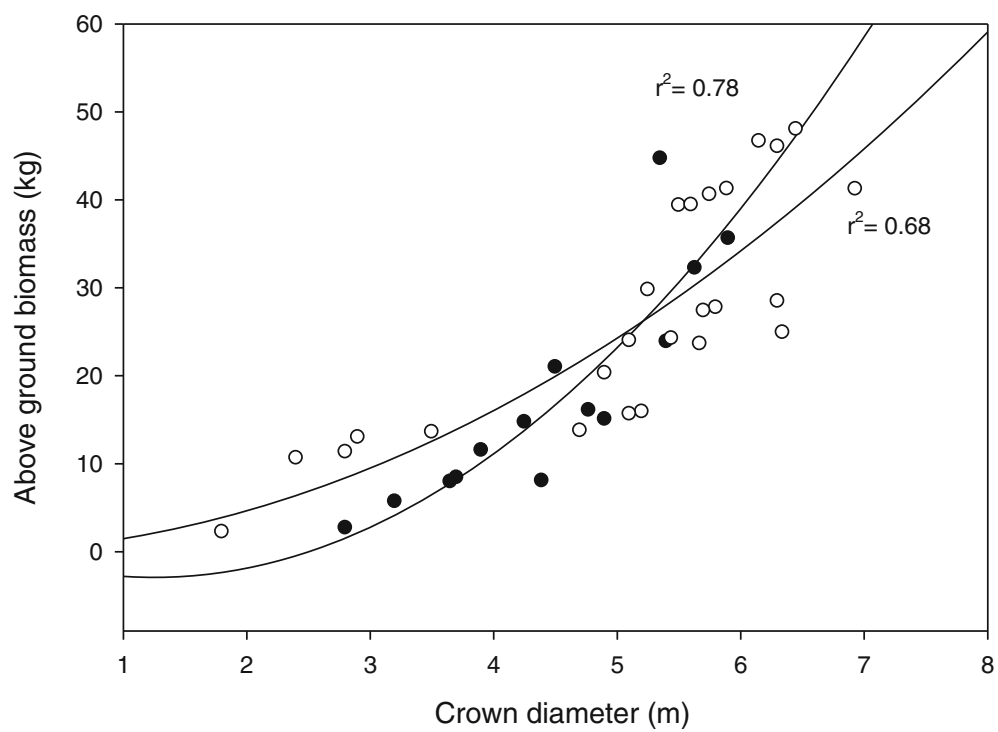

Fig. 4 Regression lines of total dry biomass (in kg) versus Crown diameter (CD) (open circles) for Juniperus procera and (filled circles) for Acacia abyssinica

carbon stocks of forests in moist Bale forest, Ethiopia (Watson et al. 2013), our results were fairly small. Compared to the average carbon stocks of $21.53 \mathrm{Mt} / \mathrm{ha}$ reported by (Beyene et al. 2013) in four regions of Ethiopia our results fitted quite well.

The four times higher biomass carbon in the community forest compared to the grazing land could be due to the difference in the total number of stems and diameter (Table 4). In grazing lands, the low standing biomass carbon is a result of free grazing practices and human interference, resulting in severe overgrazing, which affects regeneration and growth of herbaceous plant species negatively and suppresses woody vegetation growth (Mekuria and Yami 2013). A study in Ethiopia by Taddese et al. (2002); (Yayneshet et al. 2009) demonstrated that free grazing resulted in lower plant biomass when compared to non-grazing plots due to its impact on soil physical properties. Other studies conducted in

Table 3 Estimated carbon (C) stocks (Mg/ha) in plant biomass across the three management treatments, i.e. community forest, exclosure and communal grazing land

\begin{tabular}{lcccc}
\hline C contents of & $\begin{array}{l}\text { Managed } \\
\text { forest }\end{array}$ & Exclosure & $\begin{array}{l}\text { Grazing } \\
\text { land }\end{array}$ & $p$-value \\
\hline Trees & $40.99^{\mathrm{a}} \pm 0.40$ & $11.63^{\mathrm{b}} \pm 0.24$ & $4.6^{\mathrm{c}} \pm 0.19$ & $<0.0001$ \\
Shrubs & $3.72^{\mathrm{b}} \pm 0.04$ & $4.27^{\mathrm{a}} \pm 0.05$ & $1.15^{\mathrm{c}} \pm 0.01$ & $<0.0001$ \\
Herbs & $1.77^{\mathrm{b}} \pm 0.03$ & $1.92^{\mathrm{a}} \pm 0.018$ & $0.45^{\mathrm{c}} \pm 0.01$ & $<0.0001$ \\
Below ground & $11.62^{\mathrm{a}} \pm 0.10$ & $4.45^{\mathrm{b}} \pm 0.06$ & $1.55^{\mathrm{c}} \pm 0.04$ & $<0.0001$ \\
biomass & & & & \\
Total (Mg/ha) & $58.11^{\mathrm{a}} \pm 0.50$ & $22.29^{\mathrm{b}} \pm 0.30$ & $7.76^{\mathrm{c}} \pm 0.24$ & $<0.0001$ \\
\hline
\end{tabular}

Levels not connected by same letter are significantly different
Ethiopia have also shown that community-managed forests provide favorable microhabitats for herbaceous plants, which can be an effective method to improve aboveground biomass of naturally regenerating plant species (Abebe et al. 2006; Mengistu et al. 2005).

The high total biomass carbon stocks in both community-managed natural forests and exclosures suggest their significant potential to restore degraded lands and enhance ecosystem carbon content. A study in dry forests of West Africa showed that carbon stocks can be raised significantly with community forest management (Skutsch and $\mathrm{Ba}$ 2010). This increase in forest biomass carbon can be noted as evidence that the community forest is functioning as a significant carbon sink. This general increment in carbon stocks can be explained by an increase in the overall species diversity and biomass under this particular land use type. Our findings support research indicating that carbon stock declines correspond to a decline in vegetation canopy density (Dewi et al. 2009; Mekuria et al. 2009; Solichin and Steinmann 2011), which highlights how strongly land use change affects the

Table 4 Rang of tree diameters at breast height (DBH in $\mathrm{cm}$ ) and average number of stems under different land use types across Gergera watershed, Ethiopia

\begin{tabular}{lcll}
\hline Land use type & $\begin{array}{l}\text { DBH } \\
\text { (min and max) }\end{array}$ & $\begin{array}{l}\text { \# of } \\
\text { stems/plot }\end{array}$ & $\begin{array}{l}\text { \# woody } \\
\text { species/plot }\end{array}$ \\
\hline Managed forest & $3.5-22.8$ & 32 & 8 \\
Exclosure & $2.1-14.9$ & 15 & 6 \\
Grazing land & $3.2-15.6$ & 7 & 2 \\
\hline
\end{tabular}


amount and composition of plant species and aboveground biomass. Disturbances exert persistent influence over carbon cycling in forest ecosystems (Fahey et al. 2009) and are increasingly recognized as an important driver of forest carbon stocks across very large areas (Goward et al. 2008; Kurz et al. 2008). A study by Mwendera et al. (1997) in natural pastures of Ethiopian highlands found that heavy grazing significantly reduced vegetative cover and biomass yields.

Management intervention in natural forests across the globe has increased wood production, carbon sequestration, besides its benefits in terms of biodiversity conservation and watershed protection (Canadell and Raupach 2008; Wagner et al. 2006; Yitebitu et al. 2010). The average accumulation rate of carbon dioxide in managed forests is around $5.5 \mathrm{Mg} \mathrm{ha}^{-1}$ year $^{-1}$ in woodlands, and in tropical rainforests, subtropical forests, and lowland forests, while unmanaged tropical rainforests grow at a rate of about $0.5 \mathrm{Mg} \mathrm{ha}^{-1}$ year $^{-1}$ (Lewis et al. 2009), which sums up to an about 40-fold increase in annual yields.

\section{Conclusions}

The tree species selected for our model development were representative of those found in the highland areas of Ethiopia. Hence, by measuring only the stem diameter of these species, biomass, and carbon of the woody vegetation can now easily be predicted for other areas in the Ethiopian highlands using our allometric equations. The result of the study substantiates that community-managed forests are a viable option for conserving ecosystem functions and for storing carbon in the long term. The total carbon produced from the community forest is higher than that of open grazing land and that of exclosures, highlighting that human intervention can actively stimulate further carbon stock accummulation. Although it is difficult to determine the long-term potential and the equilibrium state of carbon dynamics as it may change over time, we have shown that it is possible to calculate the existing stored amount of carbon in the community forests. Further studies on soil organic carbon stocks of community-managed forest are needed to understand long-term storage below-ground.

Community managed forests should be considered for carbon trade as they provide a high carbon sink. Our results are directly relevant to international climate change mitigation initiatives such as Reduced Emissions from Deforestation and Forest Degradation (REDD) and deforestation prevention activities. We conclude that changing of ownership from state forest to local communities, coupled with payments for improved carbon storage, therefore, highly can contribute to climate change mitigation.

\section{Acknowledgements}

The authors would like to acknowledge Mr. Kahsu for his assistance during field work activities and Ms. Askal Weldu for her assistance during laboratory analyses. We are grateful to the two anonymous referees for constructive comments on an earlier version of this manuscript.

\section{Funding}

This study was financially supported by Swedish International Development Agency and Mekelle University.

\section{Authors' contributions}

NS, EB, and TT designed the study. NS conducted the laboratory experiment. NS and EB analyzed the data. NS, EB, TT, ACT, and KM wrote the manuscript. All authors read and approved the final manuscript.

\section{Competing interests}

The authors declare no competing financial interests. The funders had no role in study design, data collection and analysis, decision to publish, or preparation of the manuscript.

\section{Publisher's Note}

Springer Nature remains neutral with regard to jurisdictional claims in published maps and institutional affiliations.

\section{Author details}

${ }^{1}$ Department of Land Resources Management and Environmental Protection, Mekelle University, P.O. Box 231, Mekelle, Ethiopia. ${ }^{2}$ Faculty of Environment sciences and Natural Resources Management, Norwegian University of Life Sciences, P.O. Box 5003No-1432 Ås, Norway. ${ }^{3}$ Department of Natural Resources Economics and Management, Mekelle University, P.O. Box 231, Mekelle, Ethiopia. ${ }^{4}$ Agroecology in the Tropics and Subtropics, University of Hohenheim, Stuttgart, Germany. ${ }^{5}$ Nelson Mandela African Institution of Science and Technology, Arusha, Tanzania. ${ }^{6}$ World Agroforestry Centre (ICRAF), ILRI Campus, P.O. Box 5689, Addis Ababa, Ethiopia.

Received: 14 March 2017 Accepted: 19 May 2017

Published online: 20 June 2017

\section{References}

Abebe MH, Oba G, Angassa A, Weladji RB (2006) The role of area enclosures and fallow age in the restoration of plant diversity in northern Ethiopia. Afr J Ecol 44(4):507-514

Aerts R, Nyssen J, Haile M (2009) On the difference between "exclosures" and "enclosures" in ecology and the environment. J Arid Environ 73(8):762-763

Agrawal A, Chhatre A, Hardin R (2008) Changing governance of the world's forests. Science 320(5882):1460-1462. doi:10.1126/science.1155369

Alemu B (2012) Carbon stock potentials of woodlands and land use and land cover changes in north western lowlands of Ethiopia

Anderson J (2000) Four considerations for decentralized forest management: subsidiarity, empowerment, pluralism and social capital, Decentralization and devolution of forest management in Asia and the Pacific., pp 17-27

Aynekulu E (2011) Forest diversity in fragmented landscapes of northern Ethiopia and implications for conservation. A PhD thesis. Rheinschen FriedrichWilhems Universitat, Bonn

Ba $L$ (2006) The regeneration of Tomboroconto forest, Senegal', Can Carbon Income Combat Forest Degradation

Bekele Y, Tadesse N, Konka B (2012) Preliminary study on the impact of water quality and irrigation practices on soil salinity and crop production, Gergera Watershed, Atsbi-Wonberta, Tigray, Northern Ethiopia. Momona Ethiop J Sci $4(1): 29-46$

Berhane $H$ (2008) Assessment of the water resources potential and quality in the Gergera Watershed Atsbi-Womberta Woreda, eastern Zone, Tigray, Ethiopia

Beyene AD, Bluffstone R, Mekonnen A (2013) Community controlled forests, carbon sequestration and REDD+: some evidence from Ethiopia

Bishaw B (2001) Deforestation and land degredation in the Ethiopian highlands: a strategy for physical recovery. Northeast Afr Stud 8(1):7-25

Bojö J, Cassells D (1995) Land degradation and rehabilitation in Ethiopia: a reassessment. World bank. Africa region. Technical department. Environmentally sustainable development division.

Bowler D, Buyung-Ali L, Healey JR, Jones JP, Knight T, Pullin AS (2010) The evidence base for community forest management as a mechanism for 
supplying global environmental benefits and improving local welfare. CEE Review. Bangor University, Bangor, pp. 08-011.

Bray DB, Merino-Pérez L, Barry D (2009) The community forests of Mexico: managing for sustainable landscapes. University of Texas Press, Austin.

Brovkin V, Sitch S, Von Bloh W, Claussen M, Bauer E, Cramer W (2004) Role of land cover changes for atmospheric $\mathrm{CO} 2$ increase and climate change during the last 150 years. Glob Chang Biol 10(8):1253-1266. doi:10.1111/j. 1365-2486.2004.00812.x

Brown S (1997) Estimating biomass and biomass change of tropical forests: a primer (Vol. 134). Food \& Agriculture Org, Rome.

Brown S (2002) Measuring carbon in forests: current status and future challenges. Environ Pollut 116(3):363-372, doi: https://doi.org/10.1016/S0269-7491(01)00212-3

Cairns MA, Brown S, Helmer EH, Baumgardner GA (1997) Root biomass allocation in the world's upland forests. Oecologia 111(1):1-11

Canadell JG, Raupach MR (2008) Managing forests for climate change mitigation. Science 320(5882):1456-1457

Chaturvedi RK, Raghubanshi AS, Singh JS (2011) Carbon density and accumulation in woody species of tropical dry forest in India. For Ecol Manag 262(8):1576-1588, doi: https://doi.org/10.1016/j.foreco.2011.07.006

Chave J, Réjou-Méchain M, Búrquez A, Chidumayo E, Colgan MS, Delitti WBC, Duque A, Eid T, Fearnside PM, Goodman RC, Henry M, Martínez-Yrízar A, Mugasha WA, Muller-Landau HC, Mencuccini M, Nelson BW, Ngomanda A, Nogueira EM, Ortiz-Malavassi E, Pélissier R, Ploton P, Ryan CM, Saldarriaga JG, Vieilledent G (2014) Improved allometric models to estimate the aboveground biomass of tropical trees. Glob Chang Biol 20(10):3177-3190. doi:10.1111/gcb.12629

Chhatre A, Agrawal A (2009) Trade-offs and synergies between carbon storage and livelihood benefits from forest commons. Proc Natl Acad Sci 106(42): 17667-17670. doi:10.1073/pnas.0905308106

Condit R (2008) Methods for estimating aboveground biomass of forest and replacement vegetation in the tropics. Center for Tropical Forest Science and ForestGeo Smithsonian Tropical Research Institute, Washington.

Darbyshire I, Lamb H, Umer M (2003) Forest clearance and regrowth in northern Ethiopia during the last 3000 years. The Holocene 13(4):537-546. doi:10.1191/ 0959683603hl644rp

Defries RS, Bounoua L, Collatz GJ (2002) Human modification of the landscape and surface climate in the next fifty years. Glob Chang Biol 8(5):438-458

Dewi S, Khasanah N, Rahayu S, Ekadinata A, Van Noordwijk M (2009) Carbon footprint of Indonesian palm oil production: a pilot study. Bogor, Indonesia. World Agroforestry Centre-ICRAF, SEA Regional Office, 8.

Eshete G, Ståhl G (1998) Functions for multi-phase assessment of biomass in acacia woodlands of the Rift Valley of Ethiopia. For Ecol Manag 105(1):79-90

Fahey TJ, Woodbury PB, Battles JJ, Goodale CL, Hamburg SP, Ollinger SV, Woodall CW (2009) Forest carbon storage: ecology, management, and policy. Front Ecol Environ 8(5):245-252

Fayolle A, Doucet J-L, Gillet J-F, Bourland N, Lejeune P (2013) Tree allometry in Central Africa: Testing the validity of pantropical multi-species allometric equations for estimating biomass and carbon stocks. For Ecol Manag 305:2937, doi: https://doi.org/10.1016/j.foreco.2013.05.036

Fitsum H, Pender J, Nega G (1999) Land degradation in the highlands of Tigray, and strategies for sustainable land management. Socioeconomic and policy research working paper No. 25. International Livestock Research Institute. In MA Jabbar (Ed.). International Livestock Research Institute, Addis Ababa.

Gebremedhin B, Pender J, Tesfay G (2003) Community natural resource management: the case of woodlots in northern Ethiopia. Environ Dev Econ 8(01):129-148

Gessesse TA (2016) Above-and belowground carbon stocks in semi-arid land-use systems under integrated watershed management in Gergera watershed. Universitäts-und Landesbibliothek Bonn, Ethiopia

Giday K, Eshete G, Barklund P, Aertsen W, Muys B (2013) Wood biomass functions for Acacia abyssinica trees and shrubs and implications for provision of ecosystem services in a community managed exclosure in Tigray, Ethiopia. J Arid Environ 94:80-86

Goward SN, Masek JG, Cohen W, Moisen G, Collatz GJ, Healey S, Houghton R, Huang C, Kennedy R, Law B (2008) Forest disturbance and North American carbon flux. Eos, Trans Am Geophysical Union 89(11):105-106

Hairiah K, Dewi S, Agus F, Velarde SJ, Ekadinata A, Rahayu S, van Noordwijk M (2011) Measuring carbon stocks across land use systems: a manual, World Agroforestry Centre-ICRAF, South East Asia Regional Office, Bogor, Indonesia

Hasen-Yusuf M, Treydte A, Abule E, Sauerborn J (2013) Predicting aboveground biomass of woody encroacher species in semi-arid rangelands, Ethiopia. J Arid Environ 96:64-72
Henry M, Picard N, Trotta C, Manlay R, Valentini R, Bernoux M, Saint André L (2011) Estimating tree biomass of sub-Saharan African forests: a review of available allometric equations. Silva Fennica 45(3B):477-569

Hoben A (1995) Paradigms and politics: the cultural construction of environmental policy in Ethiopia. World Dev 23(6):1007-1021

Houghton R (2007) Balancing the global carbon budget. Annu Rev Earth Planet Sci 35:313-347

Kangas A, Maltamo M (2006) Forest inventory: methodology and applications (Vol. 10). Springer Science \& Business Media, Dordrecht.

Ketterings QM, Coe R, van Noordwijk M, Palm CA (2001) Reducing uncertainty in the use of allometric biomass equations for predicting above-ground tree biomass in mixed secondary forests. For Ecol Manag 146(1):199-209

Kurz WA, Dymond C, Stinson G, Rampley G, Neilson E, Carroll A, Ebata T, Safranyik $L$ (2008) Mountain pine beetle and forest carbon feedback to climate change. Nature 452(7190):987-990

Lewis SL, Lopez-Gonzalez G, Sonké B, Affum-Baffoe K, Baker TR, Ojo LO, Phillips OL, Reitsma JM, White L, Comiskey JA (2009) Increasing carbon storage in intact African tropical forests. Nature 457(7232):1003-1006

Malhi Y, Baker TR, Phillips OL, Almeida S, Alvarez E, Arroyo L, Chave J, Czimczik Cl, Fiore AD, Higuchi N (2004) The above-ground coarse wood productivity of 104 Neotropical forest plots. Glob Chang Biol 10(5):563-591

Malimbwi R, Solberg B, Luoga E (1994) Estimation of biomass and volume in miombo woodland at Kitulangalo Forest Reserve, Tanzania. J Trop For Sci 7(2):230-242

Mate R, Johansson T, Sitoe A (2014) Biomass equations for tropical forest tree species in Mozambique. Forests 5(3):535

Mekuria W (2013) Changes in regulating ecosystem services following establishing exclosures on communal grazing lands in Ethiopia: a synthesis. J Ecosystems. doi: $h$ ttp://dx.doi.org/10.1155/2013/860736

Mekuria W, Yami M (2013) Changes in woody species composition following establishing exclosures on grazing lands in the lowlands of Northern Ethiopia. Afr J Environ Sci Technol 7(1):30-40

Mekuria W, Veldkamp E, Haile M (2009) Carbon stock changes with relation to land use conversion in the lowlands of Tigray, Ethiopia, Paper presented at the Proceedings of Conference on International Research on Food Security, Natural Resource Management and Rural Development; Proceedings of the 36th Meeting of the Italian Society of Agronomy

Mengistu T, Teketay D, Hulten H, Yemshaw Y (2005) The role of enclosures in the recovery of woody vegetation in degraded dryland hillsides of central and northern Ethiopia. J Arid Environ 60(2):259-281

Mwendera EJ, Saleem MAM, Woldu Z (1997) Vegetation response to cattle grazing in the Ethiopian highlands. Agric Ecosyst Environ 64(1):43-51, https://dx.doi.org/10.1016/S0167-8809(96)01128-0

Ngomanda A, Engone Obiang NL, Lebamba J, Moundounga Mavouroulou Q, Gomat H, Mankou GS, Loumeto J, Midoko Iponga D, Kossi Ditsouga F, Zinga Koumba R, Botsika Bobé KH, Mikala Okouyi C, Nyangadouma R, Lépengué N, Mbatchi B, Picard N (2014) Site-specific versus pantropical allometric equations: which option to estimate the biomass of a moist central African forest? For Ecol Manag 312:1-9, doi: https://doi.org/10. 1016/j.foreco.2013.10.029

Nyssen J, Poesen J, Moeyersons J, Deckers J, Haile M, Lang A (2004) Human impact on the environment in the Ethiopian and Eritrean highlands-a state of the art. Earth Sci Rev 64(3):273-320

Nyssen J, Haile M, Naudts J, Munro N, Poesen J, Moeyersons J, Frankl A, Deckers J, Pankhurst R (2009) Desertification? Northern Ethiopia re-photographed after 140 years. Sci Total Environ 407(8):2749-2755

Pagdee A, Y-s K, Daugherty PJ (2006) What makes community forest management successful: a meta-study from community forests throughout the world. Soc Nat Resour 19(1):33-52

Pearson T, Walker S, Brown S (2005) Sourcebook for land use, land-use change and forestry projects. Winrock International and the Bio-carbon fund of the World Bank, Arlington

Ravindranath N, Ostwald M (2008) Methods for estimating above-ground biomass, Carbon Inventory Methods Handbook for Greenhouse Gas Inventory, Carbon Mitigation and Roundwood Production Projects., pp 113-147

Roy J, Mooney HA, Saugier B (2001) Terrestrial global productivity. Academic Press, San Diego.

Skutsch MM, Ba L (2010) Crediting carbon in dry forests: the potential for community forest management in West Africa. Forest Policy Econ 12(4):264-270

Skutsch M, Solis S (2011) How much carbon does community forest management save., Community Forest Monitoring for the Carbon Market 
Solichin ML, Steinmann K (2011) Tier 3 biomass assessment for baseline emission in Merang Peat Swamp Forest, Paper presented at the International Conference on Tropical Wetlands of Indonesia, Bali

Sunderlin WD, Hatcher J, Liddle M (2008) From exclusion to ownership? Challenges and opportunities in advancing forest tenure reform. Rights and Resources Initiative, Washington.

Supriya Devi L, Yadava PS (2009) Aboveground biomass and net primary production of semi-evergreen tropical forest of Manipur, north-eastern India. J For Res 20(2):151-155. doi:10.1007/s1 1676-009-0026-y

Taddese G, Saleem MM, Abyie A, Wagnew A (2002) Impact of grazing on plant species richness, plant biomass, plant attribute, and soil physical and hydrological properties of vertisol in East African highlands. Environ Manag 29(2):279-289

Tesfaye Y (2011) Participatory forest management for sustainable livelihoods in the Bale Mountains, Southern Ethiopia, vol 2011

Tietema T (1993) Biomass determination of fuelwood trees and bushes of Botswana, Southern Africa. For Ecol Manag 60(3):257-269

Ubuy MH, Gebrehiwot K, Raj AJ (2014) Biomass estimation of exclosure in the Debrekidan Watershed, Tigray Region, Northern Ethiopia. Int J Agric Forestry 4(2):88-93. doi:10.5923/j.ijaf.20140402.07

Vashum KT, Jayakumar S (2012) Methods to estimate above-ground biomass and carbon stock in natural forests-a review. J Ecosyst Ecogr 2(4):1-7, doi: http:// dx.doi.org/10.4172/2157-7625.1000116

Wagner RG, Little KM, Richardson B, McNabb K (2006) The role of vegetation management for enhancing productivity of the world's forests. Forestry: An Int J Forest Res 79(1):57-79. doi:10.1093/forestry/cpi057

Watson C, Mourato S, Milner-Gulland EJ (2013) Uncertain Emission Reductions from Forest Conservation: REDD in the Bale Mountains, Ethiopia. Ecol Soc. 18(3). doi: 10.5751/ES-05670-180306

Yayneshet T, Eik LO, Moe SR (2009) The effects of exclosures in restoring degraded semi-arid vegetation in communal grazing lands in northern Ethiopia. J Arid Environ 73(4-5):542-549, doi: https://doi.org/10.1016/j. jaridenv.2008.12.002

Yigardu M (2001) Above Ground Biomass of the Dominant Tree Species on Farmlands in Sirinka Catchment, North Wolo, Ethiopia. Swedish University of Agricultural Sciences, Skinnskatteberg.

Yitebitu M, Zewdu E, Sisay N (2010) A review on Ethiopian Forest Resources: current status and future management options in view of access to carbon finances, Prepared for the Ethiopian climate research and networking and the United Nations development programme (UNDP). Addis Ababa, Ethiopia

Zahabu E (2006a) Case Study Handei village forest reserve, Tanzania, Can Carbon Income Combat Forest Degradation? Community Forest Management for Climate Mitigation and Poverty Alleviation., p 15

Zahabu E (2006b) Kitulangalo forest area, Tanzania, Community Forest Management as a Carbon Mitigation Option., p 0

Zianis D, Seura SM (2005) Biomass and stem volume equations for tree species in Europe (Vol. 4). Finnish Society of Forest Science, Finnish Forest Research Institute, Helsinki.

\section{Submit your manuscript to a SpringerOpen ${ }^{\circ}$ journal and benefit from:}

- Convenient online submission

- Rigorous peer review

- Open access: articles freely available online

- High visibility within the field

- Retaining the copyright to your article

Submit your next manuscript at $>$ springeropen.com 